\title{
Measurement and Evaluation of Indoor Radon Concentration in a Campus in Shenbei District
}

\author{
Wenping Zhou ${ }^{1,2, a}{ }^{*}$, Wei Sheng ${ }^{1, b}$, Ziyao Shao ${ }^{3, a}$, Ruiqing Zhang ${ }^{1, c}$, Wei Niu ${ }^{1, d}$, \\ Fan $\mathrm{Li}^{1, \mathrm{a}}$ and Meiling Tang ${ }^{1, \mathrm{a}}$ \\ ${ }^{1}$ Shenyang Institute of Engineering, Shenyang, China \\ ${ }^{2}$ School of Material and Metallurgy North-eastem University College, Shenyang, China \\ ${ }^{3}$ Architecture Design \& Research Group, Beijing, China \\ azhouwp@sie.edu.cn, ${ }^{\mathrm{b}}$ sheng-wei01@263.net, 'dlxyzrq2001@163.com, ${ }^{\mathrm{d}}$ flysky168@sina.com
}

\begin{abstract}
Keywords: Background radiation; Radon concentration; Limiting value of radioprotection; Double-filter method
\end{abstract}

\begin{abstract}
The radon concerchitntration in the classroom, dormitory, laboratory and recording room of a campus in Shenbei was measured and calculated by the FT648 radon measuring instrument. The results show that the levels of radon concentration in a student dormitory and classroom were lower than national limitation of radon concentration. However, radon concentration levels of student laboratory and studio are generally higher than $200 \mathrm{~Bq} / \mathrm{m}^{3}$, the measurement value of radon concentration in laboratory would be higher than national dose limit. It will adversely affect the health of students. In this regard, a proposal to monitor the radon concentration in the laboratory in a long-term is given and the suggestions about precaution and decrease it is taken.
\end{abstract}

\section{Introduction}

Radon is a radioactive gas which is widely exist in the world. According to the report from UNSCEAR Committee in 1993 , it can be evaluated that the quantity of radon gas and its ramification are absorbed by the local people is $1.2 \mathrm{mSv}$ per person per year. It is about half contents of all natural radiation levels [1]. Excessive inhalation can cause severe diseases of human's hematologic and respiratory systems[2,3]. There are three kinds of natural radio systems in nature, series of Uranium (starting from 238U), Actinium (starting from 235U), Thorium (starting from 232Th). Radon (222Rn) and its isotope $219 \mathrm{Rn}$ and $220 \mathrm{Rn}$ are the sole elements with radioactive gas in these three natural systems, respectively. $235 \mathrm{U}$ is always symbiotic with $238 \mathrm{U}$, and $232 \mathrm{Th}$ is also symbiotic with $238 \mathrm{U}$ under certain conditions. In the crust, $238 \mathrm{U}$ is common, which means radon is everywhere with different level of concentration. Research have shown that people stay or work indoor for a long time which is much higher than that outdoor. Indoor and outdoor retention time ratio of the world population weighted average is 4.0 [4].Most of the radiation dose which is caused by radon and its ramification come from interior[5]. And indoor time of students is even higher than the average time of other social groups. Therefore, it is very important to young people's health by paying attention to the radioactivity level of indoor radon in the campus. Radon of indoor air is generally referred to $222 \mathrm{Rn}$. Because $238 \mathrm{U}$ is occupied $99.28 \%$ of natural uranium, and $235 \mathrm{U}$ is accounted for only $0.714 \%$. Therefore, $219 \mathrm{Rn}$ is less, and the source of $220 \mathrm{Rn}$ is from the surface $(\sim 1 \mathrm{~mm})$ materials in room (its level is less than or equal to $1.25 \%$ of $222 \mathrm{Rn}$ )[6]. Radon of indoor air is mainly from the following aspects[ 7]: building foundation and surrounding soil, building materials, household fuel, domestic water and radon of outdoor air. And it's also relative to the floor, housing structure, decoration, decoration materials, living time and other factors. On average level in the world, about $60.4 \%$ of indoor radon comes from building foundation and surrounding soil, $19.5 \%$ and $17.8 \%$ [8] of the rest is from building materials and outdoor air, respectively. 


\section{Protection Standard and Limit Value of Indoor Radon}

Around the world,there are different limit value for radon concentration in campus, shown as Table 1. We can find that, most of countries demand that the limit value of radon concentration in classroom is equal to that of general residential building. However, IAEA, ICRP and the rest few countries are considered of working hours. It can be seen that: Holland has the most stringent requirements in radon concentration in classroom, the lilit value is $20 \mathrm{Bqm}-3$ whatever in school or residential building. While the limit value in ICRP is up to $1500 \mathrm{Bqm}-3$. On the one hand, there is a big difference in the level of radiation in various countries, on the other hand, the limits of the standard can be demanded strictly.

China has norm in controlling of civil construction's indoor pollution(50325-2001 GB), which has been published in November 26th 2001, and implemented in January 1st, 2002. This specification divided civil building into two categories according to the requirements of controlling indoor pollution: class I civil building include residence, kindergartens, buildings for senior citizens, hospitals, schools, etc.; class II include of office buildings, stores, hotels, entertainments, libraries, bookstores, gymnasium, exhibition halls, waiting rooms for public transport, restaurants, barber shops and so on. The limit values of indoor radon concentration for these two classes are $200 \mathrm{~Bq} / \mathrm{m} 3$ and $400 \mathrm{~Bq} / \mathrm{m} 3$, respectively. In the school, the limitation of the radon concentration should be 200 $\mathrm{Bq} / \mathrm{m} 3$.

Table 1 Comparison of limitation of radon concentration in classroom and civil building[9]

\begin{tabular}{|l|c|c|}
\hline Country & Classroom $\left[\mathrm{Bqm}^{-3}\right]$ & Civil building[Bqm \\
& -3 \\
\hline Australia & 1000 & 200 \\
\hline Austria & 400 & 400 \\
\hline Canada & 800 & 800 \\
\hline Finland & 400 & 400 \\
\hline German & 250 & 250 \\
\hline Ireland & 150 & 200 \\
\hline Luxembourg & 150 & 150 \\
\hline Holland & 20 & 20 \\
\hline Norway & 800 & 200 \\
\hline Sweden & 400 & 400 \\
\hline Switzerland & 400 & 1000 \\
\hline U.S.A & 150 & 150 \\
\hline IAEA & 1000 & $200-600$ \\
\hline ICRP & $500-1500$ & $200-600$ \\
\hline
\end{tabular}

\section{Using Double-filter Method to Detect the Concentration of Indoor Radon at a School in Shenbei District}

Principle of Detecting $\mathbf{R n}$ by Using Double-filter Method. The national standard-GB/T 14582 - 1993 The methods of detecting radon in air sets the rules of detecting radon and its derivative which includes six methods of measurements ${ }^{[10]}$. They are: Track-etch Method, Active Carbon Measuring Method, Double-filter Method, Electrometer Method, Scintillation Chamber Method and Balloon Method.

In this essay, the Double-filter Method is being used. Double-filter Method[7] originates from America, and became popular in the early 1970s. This method is a rapid detection technology, which can measure the concentration of radon and get the result quickly. Also, the method contains the capability of collect the sampling automatically. Fig. 1 shows the structural model of collecting of 
radon sampling by using Double-filter Method. Double-filter Method includes two phases in practice: sample phase and testing phase. During the sample phase, the inlet membrane filters the radon derivative that already exists in air, and let the pure radon flows through the tube. After flowing into the tube, the pure radon generates its derivative, and the derivative will be collected as it flows to the outlet end. During the testing phase, the outlet membrane is taken out and the radiation activation of Alpha particle will be measured. According to the relation between the growth of derivative and the concentration of radon, and the radiation activation of Alpha particle from the outlet membrane, the concentration of radon can be measured.

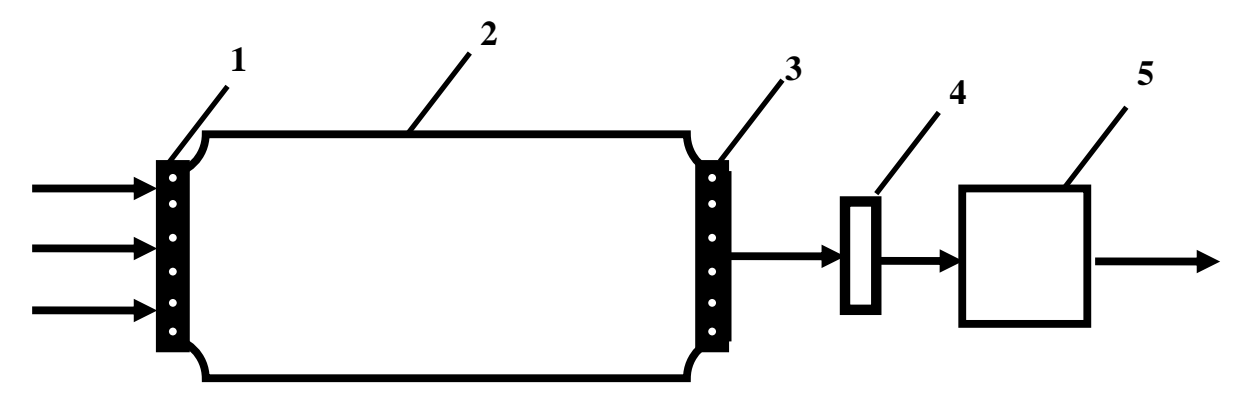

1-inlet film; 2-decay tube; 3-export film; 4-flowmeter; 5- pump

Figure 1. Double-filter method structural diagram

The main advantage of double-filter method is that the lower limit of determinand concentration can be really low, also with the high sensitivity and the short testing time. The disadvantage is that the strict requirement for clean outlet membrane.

FT648, the improved device type to measure radon, is being used in this experiment. The device is porTable and can be used in the environment. The main usage of the device is to measure radon that contains in the gas sample. Meanwhile, it can measure both existed and potential concentrations of radon. Also, it can track the real-time concentration of the daughter nuclides of radon and Th. The FT648 is being used in the experiment due to the following reasons. In the experiment, $222 \mathrm{Rn}$ is considered as the main resource because the factor is being considered that the flow rate is slower inside the building due to the lower 220Rn relief amount from the classrooms 'internal surfaces, which is less than $1.25 \%$ compared to $222 \mathrm{Rn}$. Hence, the concentration of $220 \mathrm{Rn}$ can be ignored in the measuring. Radon concentration can be calculated according to Thomas formula, which is converted in following Eq.1:

$$
C_{R n}=K X\left(B q \cdot m^{-3}\right) .
$$

$\mathrm{K}$ is Thomas coefficient. In this work, $\mathrm{K}=0.898$. Extraction gas time in this measurement is 15 minutes. $X$ is the Net count without bankground.

Measurement and Results of Indoor Radon Concentration in a Campus in Shenbei District. The measurement is conducted in the student dormitory, classroom, laboratory and studio. Results are shown in Table 2 to Table 5. 
Table 2 Measurement data of radon concentration in dormitories

\begin{tabular}{|c|c|c|c|c|c|c|c|}
\hline dormitory & $\begin{array}{l}\text { Ventila } \\
\text {-tion }\end{array}$ & $\begin{array}{l}\text { Tempera } \\
\text {-ture }\left[{ }^{\circ} \mathrm{C}\right]\end{array}$ & $\begin{array}{c}\text { Humidity } \\
{[\%]}\end{array}$ & $\begin{array}{c}\text { Background } \\
\text { count }[\mathrm{N}]\end{array}$ & $\begin{array}{c}\text { Count } \\
{[\mathrm{X}]}\end{array}$ & $\begin{array}{c}\text { Concen- } \\
\text { tration } \\
{\left[\mathrm{Bq} / \mathrm{m}^{3}\right]}\end{array}$ & $\begin{array}{c}\text { Average } \\
\text { Value } \\
{\left[\mathrm{Bq} / \mathrm{m}^{3}\right]}\end{array}$ \\
\hline 1 & no & 16 & 47 & 11 & 172 & 144.6 & \multirow{5}{*}{146.7} \\
\hline 2 & no & 17 & 41 & 10 & 165 & 139.2 & \\
\hline 3 & no & 16 & 43 & 9 & 151 & 127.5 & \\
\hline 4 & no & 17 & 45 & 9 & 192 & 164.3 & \\
\hline 5 & no & 17 & 44 & 10 & 186 & 158 & \\
\hline 1 & yes & 16 & 42 & 9 & 61 & 46.7 & \multirow{5}{*}{44.9} \\
\hline 2 & yes & 17 & 41 & 7 & 55 & 43.1 & \\
\hline 3 & yes & 17 & 42 & 7 & 46 & 35.02 & \\
\hline 4 & yes & 16 & 41 & 6 & 67 & 54.78 & \\
\hline 5 & yes & 16 & 43 & 6 & 56 & 44.9 & \\
\hline
\end{tabular}

As can be seen from the Table 1, when temperature and humidity of dormitories are basically in the same situation, concentrations of radon are different because of different ventilation. The concentration level is higher in unventilated condition, and the average value is $146.7 \mathrm{~Bq} / \mathrm{m} 3$. However, after ventilation, the concentration is generally decreased, the average value is $44.9 \mathrm{~Bq} / \mathrm{m} 3$. It can be seen that ventilation can effectively reduce the level of radon concentration.

Table 3 Measurement data of radon concentration in laboratories

\begin{tabular}{|c|c|c|c|c|c|c|c|}
\hline Laboratory & $\begin{array}{l}\text { Ventila } \\
\text {-tion }\end{array}$ & $\begin{array}{c}\text { Tempera } \\
- \text { ture }\left[{ }^{\circ} \mathrm{C}\right]\end{array}$ & $\begin{array}{c}\text { Humidity } \\
{[\%]}\end{array}$ & $\begin{array}{c}\text { Background } \\
\text { count }[\mathrm{N}]\end{array}$ & $\begin{array}{c}\text { Count } \\
{[\mathrm{X}]}\end{array}$ & $\begin{array}{c}\text { Concen } \\
\text {-tration } \\
{\left[\mathrm{Bq} / \mathrm{m}^{3}\right]}\end{array}$ & $\begin{array}{c}\text { Average } \\
\text { Value } \\
{\left[\mathrm{Bq} / \mathrm{m}^{3}\right]}\end{array}$ \\
\hline 1 & no & 17 & 44 & 15 & 383 & 330.5 & \\
\hline 2 & no & 16 & 43 & 18 & 411 & 352.9 & \\
\hline 3 & no & 17 & 44 & 18 & 282 & 237.1 & \multirow{2}{*}{290.1} \\
\hline 4 & no & 16 & 42 & 15 & 301 & 256.8 & \\
\hline 5 & no & 17 & 43 & 17 & 321 & 273 & \\
\hline 1 & yes & 16 & 44 & 6 & 252 & 220.9 & \\
\hline 2 & yes & 16 & 43 & 14 & 241 & 203.8 & \multirow{2}{*}{205.5} \\
\hline 3 & yes & 16 & 42 & 6 & 220 & 192.2 & \\
\hline 4 & yes & 17 & 41 & 14 & 241 & 203.8 & \\
\hline 5 & yes & 17 & 43 & 11 & 241 & 206.5 & \\
\hline
\end{tabular}

From Table 3, if neglected difference between temperature and humidity, the radon concentration of labs were generally higher without ventilation, and the average value is $290.1 \mathrm{~Bq} / \mathrm{m} 3$. Under the condition of ventilation, its concentration level is as high as $205.5 \mathrm{~Bq} / \mathrm{m} 3$. According to the most conservative estimate (students are in the laboratory everyday, radiation levels are same in four seasons), the radiation level of the laboratory will exceed the national dose limit which is $200 \mathrm{~Bq} / \mathrm{m} 3$. 
Table 4 Measurement data of radon concentration in classrooms

\begin{tabular}{|c|c|c|c|c|c|c|c|}
\hline Classroom & $\begin{array}{l}\text { Ventila } \\
\text {-tion }\end{array}$ & $\begin{array}{l}\text { Tempera } \\
\text {-ture }\left[{ }^{\circ} \mathrm{C}\right]\end{array}$ & $\begin{array}{c}\text { Humidity } \\
{[\%]}\end{array}$ & $\begin{array}{l}\text { Background } \\
\text { count }[\mathrm{N}]\end{array}$ & $\begin{array}{c}\text { Count } \\
{[\mathrm{X}]}\end{array}$ & $\begin{array}{l}\text { Concen } \\
\text {-tration } \\
{\left[\mathrm{Bq} / \mathrm{m}^{3}\right]}\end{array}$ & $\begin{array}{c}\text { Average } \\
\text { Value } \\
{\left[\mathrm{Bq} / \mathrm{m}^{3}\right]}\end{array}$ \\
\hline 1 & no & 18 & 43 & 7 & 132 & 112.25 & \multirow{5}{*}{87.64} \\
\hline 2 & no & 17 & 45 & 6 & 111 & 94.29 & \\
\hline 3 & no & 18 & 44 & 7 & 95 & 79.024 & \\
\hline 4 & no & 17 & 45 & 6 & 87 & 72.738 & \\
\hline 5 & no & 17 & 44 & 7 & 96 & 79.922 & \\
\hline 1 & yes & 18 & 44 & 4 & 75 & 63.758 & \multirow{5}{*}{56.21} \\
\hline 2 & yes & 18 & 46 & 6 & 69 & 56.574 & \\
\hline 3 & yes & 17 & 45 & 5 & 58 & 47.594 & \\
\hline 4 & yes & 18 & 46 & 4 & 64 & 53.88 & \\
\hline 5 & yes & 18 & 46 & 5 & 71 & 59.268 & \\
\hline
\end{tabular}

Table 4 shows that temperature and humidity of classrooms are basically in the same situation, indoor radon concentration levels are low whether or not ventilate. Without ventilation, the concentration is only $87.64 \mathrm{~Bq} / \mathrm{m} 3$, and concentration levels is $56.21 \mathrm{~Bq} / \mathrm{m} 3$ under the condition of ventilation.

Table 5 Measurement data of radon concentration in studios

\begin{tabular}{|c|c|c|c|c|c|c|}
\hline Studio & Ventilation & $\begin{array}{c}\text { Temperature } \\
{\left[{ }^{\circ} \mathrm{C}\right]}\end{array}$ & $\begin{array}{c}\text { Humidity } \\
{[\%]}\end{array}$ & $\begin{array}{c}\text { Background } \\
\text { count }[\mathrm{N}]\end{array}$ & $\begin{array}{c}\text { Count } \\
{[\mathrm{X}]}\end{array}$ & $\begin{array}{c}\text { Concentration } \\
{\left[\mathrm{Bq} / \mathrm{m}^{3}\right]}\end{array}$ \\
\hline 1 & no & 22 & 41 & 31 & 898 & 778.57 \\
\hline 2 & no & 22 & 40 & 25 & 961 & 840.52 \\
\hline 3 & no & 23 & 41 & 19 & 271 & 226.30 \\
\hline 1 & yes & 23 & 42 & 23 & 365 & 307.12 \\
\hline 2 & yes & 22 & 41 & 11 & 378 & 329.57 \\
\hline 3 & yes & 23 & 42 & 10 & 164 & 138.29 \\
\hline
\end{tabular}

Table 5 is the measurement data of radon concentration in studios in the school. The Table shows that data of the first two studios are greatly different with the third one without ventilation. The measurement values of first two studios are $778.57 \mathrm{~Bq} / \mathrm{m} 3$ and $840.52 \mathrm{~Bq} / \mathrm{m} 3$ which reach at high dose level. The measurement data of the third studio is over $200 \mathrm{~Bq} / \mathrm{m} 3$ before ventilation, but it is reduced to $138.29 \mathrm{~Bq} / \mathrm{m} 3$ after ventilation. Thus, ventilation plays an important role in indoor radon concentration. 


\section{Summary and Discussion}

After measuring and calculating to the radon concentration in these four places, some results can be deserved:(1)The average level of radon concentration in the students' dormitories and classrooms are below $200 \mathrm{~Bq} / \mathrm{m}^{3}$, while the radon concentration in the laboratories and the recording rooms are generally higher. (2) Good ventilation conditions can significantly reduce the indoor radon concentration. (3) According to the most conservative estimate (students are in the laboratory everyday and radiation levels are same in four seasons), the radiation level of the laboratory will exceed the national dose limit which is $200 \mathrm{~Bq} / \mathrm{m}^{3}$ even under ventilation. It is need to be monitored for a long-term and improved the experimental environment as far as possible. Moreover, some measures should be taken, such as sealing up ground and water pipe or painting walls by using anti-radon coating. (4) In studios, many devices and closing windows cause less ventilation. However, students and teachers stay at the room in a short time, so the indoor radon concentration can be reduced by strengthening ventilation. On the other hand, it should be considered whether the dose is excessive in some people who stay at the room for a long time such as students of music department. Reducing the time indoor (time is in direct proportion to the dosage) or radon concentration can deal with the problem.

\section{References}

[1] UNSCEAR rep. Radon in air D226-228.(1993) 65-66.

[2] Aarkrog A. Environmental radiation and radioactive releases. IntJ Radiat Biol 4(1990) 619-631.

[3] Pirchan. A. and Sike. H. Cancer of the lung in the miners of Jochimov. Cancer 16(1932) 681

[4] UNSCEAR rep.( 1982)

[5] Jin Yi-He,Xu Li-Ya, Fang Guo-Qiu et al. Analysis of indoor radon concentration limits at home and abroad .IMPORT INQUIRY 12 ( 2006) 16-18.

[6] KRISIUK E. M. Airborne Radioactivity in Buildings, Health Phys 38(1980) 199.

[7] ZHANG Li-jiao XIE Bo . Measurement and Protection of Indoor Radon. JCHINESE JOURNAL OF RADIOLOGICAL HEALTH 15(2006) 84- 85.

[8] Gan Yu-Lin ,Xu Ming-Fa, Xiang Hui-Yun.The indoor radiation measurement analysis of a newly built high-rise residential.building in Nanning[J].Popular Science \& Technology 15 (2013)67-70.

[9] Colgan PA and Gutierrez J. National app roaches to controllingexposure to radon . Enviroment International 22 (1996) S1083-S1092.

[10]Zhao Yong-Li, Fang Fang, LÜ Mao.J Environ Health, January 25(2008)72-73 